\title{
A review of the phytochemical support for the shifting defence hypothesis
}

\author{
Leonie J. Doorduin · Klaas Vrieling
}

Received: 29 January 2010/ Accepted: 20 August 2010/Published online: 1 September 2010

(C) The Author(s) 2010. This article is published with open access at Springerlink.com

\begin{abstract}
Several theories have been developed to explain why invasive species are very successful and develop into pest species in their new area. The shifting defence hypothesis (SDH) argues that invasive plant species quickly evolve towards new defence levels in the invaded area because they lack their specialist herbivores but are still under attack by local (new) generalist herbivores. The SDH predicts that plants should increase their cheap, toxic defence compounds and lower their expensive digestibility reducing compounds. As a net result resources are saved that can be allocated to growth and reproduction giving these plants a competitive edge over the local plant species. We conducted a literature study to test whether toxic defence compounds in general are increased in the invaded area and if digestibility reducing compounds are lowered. We specifically studied the levels of pyrrolizidine alkaloids, a toxin which is known for its beneficial and detrimental impact against specialists and generalists, respectively. Digestibility reducers did not show a clear trend which might be due to the small number of studies and traits measured. The meta analysis showed that toxic compounds in general and pyrrolizidine alkaloid levels specifically, increased significantly
\end{abstract}

L. J. Doorduin $(\bowtie) \cdot$ K. Vrieling

Ecology and Phytochemistry, Institute of Biology, Leiden

University, PO Box 9505, 2300 RA Leiden,

The Netherlands

e-mail: L.J.Doorduin@Biology.leidenuniv.nl in the invaded area, supporting the predictions of the SDH that a fast evolution takes place in the allocation towards defence.

Keywords Defence $\cdot$ EICA $\cdot$ Invasion $\cdot$ PAs $\cdot$ SDH

\section{Introduction}

With an increase in human travel intensity over the past 300 years, many species have been introduced into new areas (Long 2003). The introduction of these species has often gone unnoticed, and many of these species have probably not survived. The species that do survive in their new habitats often have a marginal existence. However, a small number of species thrive. For example $21 \%$ of the North American flora consists of exotic species (Rejmanek 2000) but only $2 \%$ of these have developed into pests. These pest species can have economic consequences as well as severe impacts on the biodiversity and ecological networks in their new ranges. For instance, the introduction of goats on islands quickly led to deforestation of these islands (Long 2003), the introduction of the cane toad in Australia has been detrimental to local fauna (Easteal 1981), and the introduction of ragwort into Australia, New Zealand and North America has led to livestock poisoning (Craig et al. 1986; Coombs et al. 2004). In addition to causing economic and ecological losses, exotic species also offer opportunities to test ecological 
theories because biological introductions function as unplanned transplant experiments (Joshi and Vrieling 2005).

Here we will restrict our discussion to introduced plant species that have become successful enough to be designated as invasive pests. A number of theories have been proposed to explain the success of such plant species in their exotic ranges. We will focus on theories that are centred on plant release from natural enemies, and these theories directly or indirectly incorporate hypotheses regarding the chemical defences of invasive plants. The main theories that have been proposed are the Evolution of Increased Competitive Ability (EICA) hypothesis (Blossey and Nötzold 1995) and the Shifting Defence Hypothesis (SDH; Müller-Schärer et al. 2004, Joshi and Vrieling 2005). The EICA hypothesis is the evolutionary extension of the Enemy Release Hypothesis (ERH; Keane and Crawley 2002). The ERH states that when plants are introduced into a new area, they leave their specialist herbivores behind and are therefore freed from detrimental herbivore pressure by these specialist herbivores. It is predicted that herbivory from local generalist herbivores is limited because newly introduced plants contain unknown, and therefore potent chemical defences to which local herbivores are not adapted (unless native relatives of the introduced plant species are present; Connor et al. 1980). This theory about chemical novelties is known as the novel weapons theory (Callaway and Ridenour 2004). Both the ERH and novel weapons theory do not predict per se a change in the chemistry of introduced plants in their exotic ranges. However, the EICA hypothesis predicts that an absence of specialist herbivores will cause plant defences against specialists to decline in exotic species over evolutionary time. The EICA hypothesis assumes that secondary metabolites act as chemical defences against specialist herbivores. It is known that many species vary genetically in composition and concentration of their secondary metabolites (Vrieling et al. 1993; Van Dam and Vrieling 1994; Arany et al. 2009). In the absence of specialist herbivores in the invasive area, selection favours plants that have lower concentrations of such compounds because these compounds are costly to produce; selection thus results in a decline in secondary metabolite concentrations over a number of generations (see Vrieling and van Wijk 1994 and review by Koricheva 2002). When plants reduce their investment in defence, they can allocate the freed resources to growth and reproduction, giving them a competitive edge over local plants. Many studies show that pest species show increased growth or reproduction compared to native individuals. The EICA therefore predicts an evolutionary change such that levels of chemical defence compounds are decreased in individuals in the invaded area compared to the individuals in the native area (Blossey and Nötzold 1995).

The SDH is a further extension of the EICA hypothesis. The SDH differentiates between defences based on their effectiveness against specialist and generalist herbivores, and couples this to types of defences (Müller-Schärer et al. 2004; Joshi and Vrieling 2005). Feeny (1976) and Rhoades and Cates (1976) developed the Apparency theory, which distinguishes between "quantitative" and "qualitative" defences in plants. Qualitative defences are toxins or deterrents against herbivores and occur in relative low quantities in plants. Quantitative defences are digestibility reducers and occur in higher concentrations. Toxins act mainly against unadapted generalist herbivores while specialist herbivores often are very well adapted to these compounds in their diet. An important class of toxins are the pyrrolizidine alkaloids (PAs), with more than 660 different structures identified in over 600 plant species. About half of these PAs formed are toxic to livestock and wildlife and also to most insects. However, specialist herbivores use these compounds for their own benefit as cues to recognize their food plant, e.g. PAs acting as an oviposition stimulant (Máčel and Vrieling 2003) and as feeding stimulant (Bernays et al. 2004).

In addition, PAs and other compounds are sometimes sequestered for the defence of the herbivore itself (Eisner and Eisner 1991). In other cases PAs amongst others have become an essential part of the herbivore's sex pheromone system, or are used as a nuptial gift (Weller et al. 1999). Because PAs and other toxins occur in low concentrations (usually less than 1 percent of the dry weight), they are assumed to be a cheap defence. Digestibility reducers occur in higher concentrations and are more expensive for the plant to produce (Glawe et al. 2003) because costs of secondary metabolites increase with their concentration (Vrieling and van Wijk 1994). However, they are believed to be less easy to circumvent by specialist herbivores and generalist herbivores. Toxins therefore 
pose a dilemma for the plants in their native ranges, and this dilemma is referred to as the specialistgeneralist dilemma (Van der Meijden 1996). Increasing PA or toxin levels protects the plant against unadapted generalist herbivores, but simultaneously makes it more vulnerable to adapted specialist herbivores. PAs and toxins concentrations are therefore constrained by opposing selective forces from specialist herbivores and small allocation cost on one hand, and from herbivory by generalist herbivores on the other hand (Fig. 1). Digestibility reducers provide protection against both generalist and specialist herbivores but have a higher allocation cost (Glawe et al. 2003). The SDH comes into play for plants introduced into areas where their specialist herbivores are absent. Expensive digestibility reducer levels are decreased at the expense of cheap toxins, yielding a net allocation gain that can be diverted to growth and reproduction. The SDH therefore predicts that toxin concentrations will increase, digestibility reducer levels will decrease, and growth and reproduction will increase upon plant introduction into a new area. Fundamental to the EICA and the SDH is the

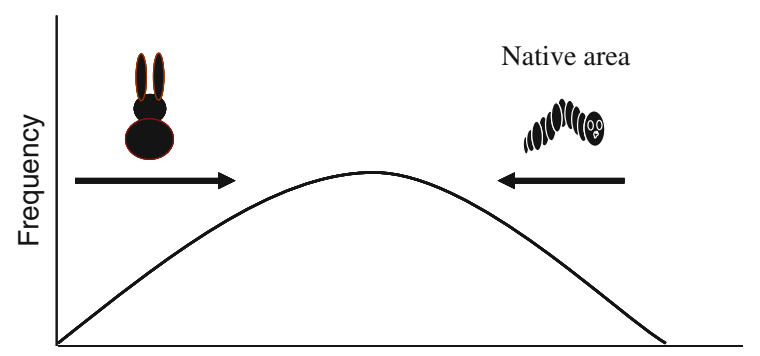

Amount of toxins

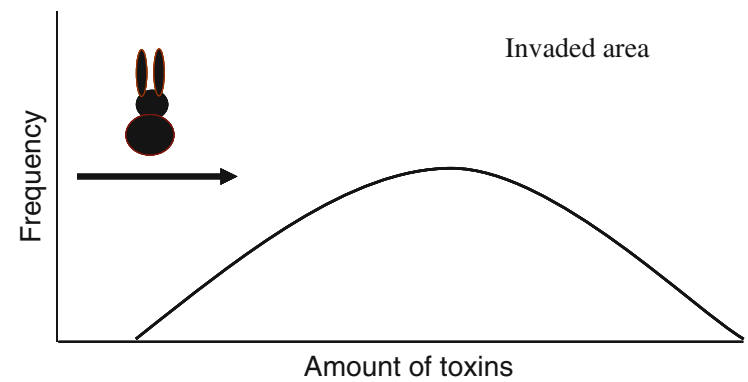

Fig. 1 Schematic overview of selection pressures of generalists and specialists in the native area and the invaded area. Under the influence of the selection pressure of the specialist herbivores in the invaded area the defence distribution has shifted to the right. Generalists are represented by a rabbit, specialists are represented by a caterpillar assumption that rapid evolutionary change takes place upon plant introduction into the new area.

We searched the literature for studies in which defence levels were measured in common garden experiments in plants from both native and invasive areas to find evidence for increased levels of toxins and decreased levels of digestibility reducers in invaded areas. Because PAs are toxins known for their beneficial impact on specialists and their detrimental impact on generalists, we expect differences in PA levels between the native and the invasive areas. As a sub study, PA levels from native and invasive plants measured in different studies were compared. Based on the SDH we expect increased levels of PAs in the invaded areas.

\section{Materials and methods}

We used the ISI Web of Science to gather data for comparing defence levels between native and invasive individuals. The following keyword combinations were typed into search for papers: invasive/invasion AND defence/defense AND plant and invasive/invasion AND common garden experiment. This search resulted in 398 papers. A first selection was made by reading the paper titles and abstracts. The majority of papers contained defence data from native or invasive individuals only; these papers were excluded. Moreover, several articles comprised data about allelopathy. The hypotheses and theories we wanted to test were not developed for allelopathic interactions and we therefore excluded these articles. Several papers could not be incorporated because they lacked quantitative data. After making this selection, we extended the literature search to the references in the articles that were dealing with our subject. With regard to digestibility reducers we included measurements of trichome density, toughness and dry matter content. These mechanical defence products were grouped with the digestibility reducers based on the study of Travers- Martin and Müller (2008). This study of matching plant defence syndromes showed that mechanical defence and digestibility reducers were clustered because the performance of specialists was the same for both defence mechanisms.

In some papers defence levels of chemical compounds were measured per genotype. For our analysis we averaged values over genotypes and populations. 
Units of measurement differed between studies and in some cases could not be converted to standard measurement units. Hedges et al. (1999) developed statistical tools for meta-analysis that can be used to compare ratios between different studies to estimate effect sizes. For each study effect sizes were calculated as $\mathrm{L}=\ln$ (value of invasive plants/value of the native plants) $=\ln$ (value of the invasive plants) $\ln$ (value of the native plants). Over all studies a weighted mean of $\mathrm{L}$ and confidence limits were calculated, taking into account sample sizes and standard errors within each study (Hedges et al. 1999). L values were returned to simple ratios by taking the antilog of the $\mathrm{L}$ value and calculating $95 \%$ confidence intervals. An antilog value of one therefore represents the situation that the level of defence in the native plants is exactly equal to the level of defence in the invasive plants. Antilog values larger than 1 indicate that the level of defences are higher in the invasive area compared to the native area. For the sub study on PAs, effect sizes were calculated in a similar way for PAs only.

For all studies except that of Willis et al. (1999), means and standard errors could be derived from the text. The study of Willis et al. (1999) was therefore not included although it supports the SDH.

\section{Results}

The literature yielded 15 publications in which plants from invaded and native areas were reared in a common garden set up, and in which toxins and/or digestibility reducers were measured (Table 1 ). In total eight different toxins were measured in nine different species yielding 13 comparisons. In three studies, comprising four data sets, PA levels were measured and these data were included in the sub study. We found four publications in which all data about digestibility reducers were available. Moreover, three other studies were found where five morphological traits such as dry matter content, trichome density or toughness were measured yielding 9 comparisons in total (Table 1). Antilog values of the weighted mean of $\mathrm{L}$ and confidence limits were 0.933 and $0.660-1.318$, respectively (see also Fig. 2). This is not in line with the expectation of the SDH that native individuals should have higher levels of digestibility reducers than invasive individuals. This meta- analysis therefore showed that digestibility reducers were not significantly decreased in plants from invaded areas as predicted by the SDH.

For toxins, antilog values of the weighted mean of $\mathrm{L}$ and confidence limits were 1.433 and 1.119-1.837, respectively (see also Fig. 2). All values were above one which is in line with the expectation of the SDH that native individuals have lower levels of toxins than invasive individuals.

The meta-analysis therefore showed that toxins were significantly increased in plants from the invaded area as predicted by the SDH. For the PAs, antilog values of the weighted mean of $\mathrm{L}$ and confidence limits were even higher than for toxins overall (resp. 2.833 and 1.844-4.354, see also Fig. 2). This finding is in line with the SDH.

\section{Discussion}

As predicted by the shifting defence hypothesis (SDH), toxin concentrations were significantly higher in invasive individuals than in native individuals. Studies that were incorporated into this meta-analysis included a number of different chemical compounds such as alkaloids, terpenes and glucosinolates. Despite big differences in chemistry, a majority of the studies showed the same pattern. Because all studies were carried out in a common garden, native and invasive individuals were exposed to identical environmental conditions. For this reason differences in defence levels are evidence for evolutionary change (Bossdorf et al. 2005). Invasive plants evolved an energetically beneficial but effective defence strategy in response to the absence of specialists. The sub study on PA levels showed even a stronger pattern compared to the overall study of toxins, with concentrations significantly higher in invasive individuals.

However, in a study by Eigenbrode et al. (2008), no difference was found in the level of pyrrolizidine alkaloids between native and invasive individuals of C. officinale. Although herbivore pressure in the invaded area was not formally measured, it appeared that plants in this area experienced less herbivory compared to the native area. Because the production of defence compounds can be costly (Vrieling and van Wijk 1994; Koricheva 2002), the optimal defence theory poses that allocation to defence should be proportional to the risk of attack (Stamp 2003). If the 
Table 1 Studies used for the analysis of toxins and digestibility reducers in native and invasive individuals

\begin{tabular}{|c|c|c|c|c|c|c|c|c|c|}
\hline \multicolumn{2}{|l|}{ Toxins } & \multicolumn{3}{|c|}{ Native } & \multicolumn{5}{|c|}{ Invasive } \\
\hline Species & Compound & $\mathrm{P} ; \mathrm{R}$ & Area & Conc. & $\mathrm{P} ; \mathrm{R}$. & Area & Conc. & Sig & Reference \\
\hline Alliaria petiolata & Sinigrin & $3 ; 30$ & EU & $16.1 \mu \mathrm{mol} / \mathrm{g}$ & $3 ; 30$ & NA & $49.6 \mu \mathrm{mol} / \mathrm{g}$ & $* *$ & (Lewis et al. 2006) \\
\hline $\begin{array}{l}\text { Senecio } \\
\quad \text { inaequidens }{ }^{\wedge}\end{array}$ & $\begin{array}{l}\text { Pyrrolizidine } \\
\text { alkaloids }\end{array}$ & $3 ; 10$ & $\mathrm{AF}$ & $0.00 \mu \mathrm{g} / \mathrm{g}$ & $3 ; 10$ & EU & $0.81 \mu \mathrm{g} / \mathrm{g}$ & $*$ & (Cano et al. 2009) \\
\hline $\begin{array}{l}\text { Senecio } \\
\quad \text { pterophorus }^{\wedge}\end{array}$ & $\begin{array}{l}\text { Pyrrolizidine } \\
\text { alkaloids }\end{array}$ & $3 ; 10$ & $\mathrm{AF}$ & $0.24 \mu \mathrm{g} / \mathrm{g}$ & $3 ; 10$ & EU & $1.04 \mu \mathrm{g} / \mathrm{g}$ & $*$ & (Cano et al. 2009) \\
\hline Senecio jacobaea ${ }^{\wedge}$ & $\begin{array}{l}\text { Pyrrolizidine } \\
\text { alkaloids }\end{array}$ & $15 ; 4$ & EU & $2.03 \mu \mathrm{g} / \mathrm{g}$ & $16 ; 4$ & $\begin{array}{l}\text { NA/AU/ } \\
\text { NZ }\end{array}$ & $3.84 \mu \mathrm{g} / \mathrm{g}$ & $* * *$ & $\begin{array}{l}\text { (Joshi and Vrieling } \\
\text { 2005) }\end{array}$ \\
\hline $\begin{array}{l}\text { Hypericum } \\
\text { perforatum }\end{array}$ & Hypericin & $17 ; 20$ & EU & $0.27 \mathrm{mg} / \mathrm{g}$ & $32 ; 20$ & NA & $0.2 \mathrm{mg} / \mathrm{g}$ & $* *$ & (Maron et al. 2004) \\
\hline $\begin{array}{l}\text { Hypericum } \\
\text { perforatum }\end{array}$ & Hypericide & $17 ; 10$ & EU & $28 \mathrm{mg} / \mathrm{g}$ & $32 ; 10$ & NA & $22.8 \mathrm{mg} / \mathrm{g}$ & n.s. & (Maron et al. 2004) \\
\hline $\begin{array}{l}\text { Centaurea } \\
\text { maculosa }\end{array}$ & Catechin & $4 ; 5$ & EU & $24 \mu \mathrm{g} / \mathrm{ml}$ & $11 ; 5$ & NA & $42 \mu \mathrm{g} / \mathrm{ml}$ & n.s. & (Ridenour et al. 2008) \\
\hline $\begin{array}{l}\text { Cynoglossum } \\
\text { officinale }^{\wedge}\end{array}$ & $\begin{array}{l}\text { Pyrrolizidine } \\
\text { alkaloids }\end{array}$ & $4 ; 10$ & EU & $0.07 \mathrm{mg} / \mathrm{g}$ & $3 ; 10$ & NA & $0.068 \mathrm{mg} / \mathrm{g}$ & n.s. & $\begin{array}{l}\text { (Eigenbrode et al. } \\
\text { 2008) }\end{array}$ \\
\hline Solidago gigantean & Sesquiterpenes & $10 ; 8$ & NA & $1.36 \mathrm{mg} / \mathrm{g}$ & $20 ; 4$ & EU & $1.25 \mathrm{mg} / \mathrm{g}$ & n.s. & $\begin{array}{l}\text { (Hull-Sanders et al. } \\
\text { 2007) }\end{array}$ \\
\hline Solidago gigantean & Diterpenes & $10 ; 8$ & NA & $1.20 \mathrm{mg} / \mathrm{g}$ & $20 ; 4$ & EU & $1.04 \mathrm{mg} / \mathrm{g}$ & n.s. & $\begin{array}{l}\text { (Hull-Sanders et al. } \\
\text { 2007) }\end{array}$ \\
\hline Lepidium draba & $\begin{array}{l}\text { Total } \\
\text { glucosinolates }\end{array}$ & $11 ; 5$ & EU & $62.34 \mu \mathrm{mol} / \mathrm{g}$ & $10 ; 5$ & NA & $71.78 \mu \mathrm{mol} / \mathrm{g}$ & n.s. & $\begin{array}{l}\text { (Müller and Martens } \\
\text { 2005) }\end{array}$ \\
\hline Lepidium draba & $\begin{array}{l}\text { Total } \\
\text { glucosinolates }\end{array}$ & $11 ; 5$ & EU & $46.4 \mu \mathrm{mol} / \mathrm{g}$ & $10 ; 5$ & NA & $43.5 \mu \mathrm{mol} / \mathrm{g}$ & n.s. & $\begin{array}{l}\text { (Müller and Martens } \\
\text { 2005) }\end{array}$ \\
\hline Alliaria petiolata & $\begin{array}{l}\text { Total } \\
\text { glucosinolates }\end{array}$ & $7 ; 10$ & EU & $0.35 \mathrm{mg} / \mathrm{g}$ & $7 ; 10$ & NA & $0.21 \mathrm{mg} / \mathrm{g}$ & n.s. & (Cipollini et al. 2005) \\
\hline \multicolumn{10}{|l|}{ Digestibility reducers } \\
\hline Silene latifolia & Trichomes & $20 ; 10$ & EU & $\begin{array}{l}84.5 \mathrm{no} . / \\
3.2 \mathrm{~mm}^{2}\end{array}$ & $20 ; 10$ & NA & $\begin{array}{l}88.5 \mathrm{no} . / \\
3.2 \mathrm{~mm}^{2}\end{array}$ & n.s. & $\begin{array}{l}\text { (Blair and Wolfe } \\
\text { 2004) }\end{array}$ \\
\hline Silene latifolia & Trichomes & $20 ; 10$ & EU & $\begin{array}{l}114 \mathrm{no} / 3.2 \\
\mathrm{~mm} 2\end{array}$ & $20 ; 10$ & NA & $\begin{array}{l}107 \mathrm{no} / \\
3.2 \mathrm{~mm}^{2}\end{array}$ & n.s. & $\begin{array}{l}\text { (Blair and Wolfe } \\
\text { 2004) }\end{array}$ \\
\hline $\begin{array}{l}\text { Centaurea } \\
\text { maculosa }\end{array}$ & Trichomes & $22 ; 5$ & EU & 94 no./cm2 & $23 ; 5$ & NA & $135 \mathrm{no} . / \mathrm{cm}^{2}$ & $* *$ & (Ridenour et al. 2008) \\
\hline Senecio jacobaea & Dry matter & $8 ; 7$ & EU & $144 \mathrm{mg} / \mathrm{g}$ & $14 ; 7$ & $\begin{array}{l}\text { NA/AU/ } \\
\text { NZ }\end{array}$ & $122 \mathrm{mg} / \mathrm{g}$ & $*$ & $\begin{array}{l}\text { (Doorduin } \\
\text { unpublished) }\end{array}$ \\
\hline Alliaria petiolata & Trypsin inhibitors & $7 ; 10$ & EU & $\begin{array}{l}11.8 \text { units/g } \\
\text { dw }\end{array}$ & $4 ; 10$ & NA & $\begin{array}{l}30.4 \text { units/g } \\
\text { dw }\end{array}$ & n.s. & (Cipollini et al. 2005) \\
\hline $\begin{array}{l}\text { Ageratina } \\
\text { adenophora }\end{array}$ & Cell wall proteint. & $5 ; 10$ & $\mathrm{ME}$ & $0.69 \mathrm{~g} / \mathrm{m} 2$ & $10 ; 10$ & $\mathrm{CH} / \mathrm{IN}$ & $0.39 \mathrm{~g} / \mathrm{m}^{2}$ & $*$ & (Feng et al. 2009) \\
\hline Fucus evanescens & Phlorotannin & $3 ; 10$ & SW & $27.9 \mathrm{mg} / \mathrm{g}$ & $3 ; 10$ & ICE & $57.1 \mathrm{mg} / \mathrm{g}$ & $*$ & (Wikström et al. 2006) \\
\hline Lythrum salicaria & Total phenolics & $6 ; 10$ & EU & $4.8 \mathrm{mg} / \mathrm{g}$ & $6 ; 10$ & NA & $3.3 \mathrm{mg} / \mathrm{g}$ & $* *$ & (Willis et al. 1999) \\
\hline Sapium sebiferum & Tannins & $1 ; 7$ & $\mathrm{CH}$ & $1.59 \%$ dr. wt. & $3 ; 8$ & NA & $0.09 \%$ dr. wt. & $*$ & $\begin{array}{l}\text { (Siemann and Rogers } \\
\text { 2001) }\end{array}$ \\
\hline
\end{tabular}

Studies used for the analysis on pyrrolizidine alkaloids alone are indicated with ${ }^{\wedge}$. In the $\mathrm{P}$; R column the number of populations are given followed by the number of replicates. In the Area column, the region of origin is indicated where EU stands for Europe, AF for Africa, NA for North America, ME for Mexico, AU for Australia, NZ for New Zealand, CH for China, IN for India, SW for Sweden and ICE for Iceland. In the Conc. column the concentration of defence compounds are indicated. Significance levels are indicated in the column Sig. with n.s. for not significant, $* P<0.05$, ** $P<0.01$ and $* * * P<0.001$ 


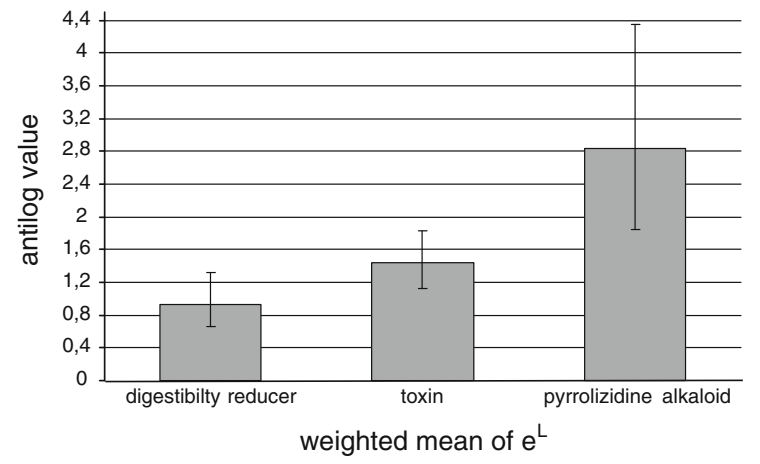

Fig. 2 To compare ratios between the studies $L$ values were used to estimate effect sizes. Weighted means of $\mathrm{L}$ are calculated as $\ln$ (value of the invasive plants/value of the native plants). The x-axis indicates the antilog of the weighted means of L. Error bars indicate the antilogs of the $95 \%$ confidence limits of the antilog of $\mathrm{L}$

herbivore pressure is (very) low in the invaded area, as in the above mentioned study, it could be more beneficial for a plant to save energy by not producing any defence products.

In a study by Hull-Sanders et al. (2007) no difference in concentration of diterpenes was found between native and invasive individuals of $S$. gigantea. A previous study showed that none of the invasive populations were infested by insects (Jakobs et al. 2004); therefore the optimal defence theory may also be responsible for this outcome. There is also some evidence that these compounds can reduce spore production by fungal pathogens (Biere et al. 2004) and therefore do not act solely as a defence against herbivores. Besides being beneficial traits, defence products can also lead to so called ecological costs (Strauss et al. 1999) such as increased susceptibility to other types of herbivores and pathogens, and deleterious effects on pollinators and herbivore predators and parasitoids. Besides herbivore defence, chemical compounds can therefore have multiple functions which can affect natural selection on chemical defences.

In a study by Maron et al. (2004), the level of hypericin was lower in invasive individuals compared to native individuals. In ongoing work no difference was found in resistance of native and invasive individuals against a specialist herbivore (Maron et al. 2004). It may be that selection in the native range by generalists has led to higher concentrations of hypericin in the native area.
Total concentration of glucosinolates was measured in leaves of the crucifer L. draba. Seedlings from the invaded range contained, as predicted by the $\mathrm{SDH}$, a higher concentration of glucosinolates. In plants of 3 months old no difference was found. However, myrosinase activity was significantly higher in invasive individuals compared to native individuals. It is suggested that this product has even stronger adverse effects as a toxin for herbivores than glucosinolates themselves (Agrawal and Kurashige 2003) and may also attract parasitoids of herbivores (Bradburne and Mithen 2000). Moreover, glucosinolates are also known for their inducibility. In a study on A. petiolata, invasive individuals contained reduced constitutive levels and increased induced levels of glucosinolates compared to native individuals (Cipollini et al. 2005). This may be a cost- saving strategy resulting from reduced selective pressure by herbivores (Koricheva et al. 2004).

The SDH also predicts a decrease in expensive digestibility reducing compounds of invasive individuals compared to native individuals. Our review of the literature did not find support for this prediction. However, most of the data consisted of morphological traits that have functions other than defence. Moreover, there can be morphological constraints for the production of defence chemistry. It is only possible to produce more terpenoids if there are more storage compartments such as resin ducts and glandular trichomes (Björkman et al. 1998). It is also known that trichomes have important functions in regulating leaf temperature and light reflection (Smith and Nobel 1977) and leaf evaporation (Brewer et al. 1991). One assumption of the SDH is that quantitative defence products are more expensive than qualitative defence products. However, this may depend on the environmental conditions of a plant. For example, leaf toughness is not necessarily expensive. Leaves can become tougher by increasing the thickness of the photosynthetic mesophyll (Read et al. 2009). In a sunny environment the costs of carbon gain due to internal self-shading are very small in relation to the increase of photosynthesis (Roderick et al. 1999). Under such conditions, toughening of leaves incurs no cost. These alternative benefits could also contribute to invasiveness and might be selected for in the invasive range. Therefore, the number of trichomes and leaf toughness are difficult to interpret in the light of quantitative defences. Besides having multiple 
functions within a particular species range, a chemical compound might also have different functions in native and invasive individuals.

Another strategy to cope with herbivory, which is not taken into account by comparing defence compounds, is regrowth capacity. It has been argued that this strategy is especially beneficial for plants that suffer from high herbivory, such as that from specialists (Van der Meijden et al. 2000). Instead of investing energy in defence, energy can be allocated to regrowth. Joshi and Vrieling (2005) indeed found evidence for this strategy. Invasive individuals without specialists had lower regrowth capacity compared to native individuals.

In conclusion, we found higher levels in invasive individuals for toxins in general and also specifically for PAs, which is in accordance with the SDH. Digestibility reducing products of native and invasive individuals did not differ. However, a smaller number of studies were available that addressed digestibility reducing defences, and a number of these defences are also known to be involved in other plant processes.

Acknowledgments We are grateful to two anonymous reviewers for their helpful comments on the manuscript and for suggesting some papers that could be included in this study. Furthermore we want to thank B. Muton-Phillips and H. Kirk for revising the English.

Open Access This article is distributed under the terms of the Creative Commons Attribution Noncommercial License which permits any noncommercial use, distribution, and reproduction in any medium, provided the original author(s) and source are credited.

\section{References}

Agrawal AA, Kurashige NS (2003) A role for isothiocyanates in plant resistance against the specialist herbivore Pieris rapae. J Chem Ecol 29:1403-1415

Arany AM, de Jong TJ, van der Meijden E (2009) Herbivory and local genetic differentiation in natural populations of Arabidopsis thaliana (Brassicaceae). Plant Ecol 201:651-659

Bernays EA, Hartmann T, Chapman RF (2004) Gustatory responsiveness to pyrrolizidine alkaloids in the Senecio specialist, Tyria jacobaeae (Lepidoptera, Arctiidae). Phys Entomol 29:67-72

Biere A, Marak HB, van Damme JMM (2004) Plant chemical defense against herbivores and pathogens: generalized defense or trade-offs? Oecologia 140:430-441

Björkman C, Kyto M, Larsson S, Niemela P (1998) Different responses of two carbon-based defences in Scots pine needles to nitrogen fertilization. Ecoscience 5:502-507
Blair AC, Wolfe LM (2004) The evolution of an invasive plant: an experimental study with Silene latifolia. Ecology 85:3035-3042

Blossey B, Nötzold R (1995) Evolution of increased competitive ability in invasive nonindigenous plants - a hypothesis. J Ecol 83:887-889

Bossdorf O, Auge H, Lafuma L, Rogers WE, Siemann E, Prati D (2005) Phenotypic and genetic differentiation between native and introduced plant populations. Oecologia 144:1-11

Bradburne RP, Mithen R (2000) Glucosinolate genetics and the attraction of the aphid parasitoid Diaeretiella rapae to Brassica. Proc R Soc Lond B Biol Sci 267:89-95

Brewer CA, Smith WK, Vogelmann TC (1991) Functional Interaction between leaf Trichomes, leaf wettability and the optical-properties of water droplets. Plant Cell Environ 14:955-962

Callaway RM, Ridenour WM (2004) Novel weapons: invasive success and the evolution of increased competitive ability. Front Ecol Environ 2:436-443

Cano L, Escarre J, Vrieling K, Sans FX (2009) Palatability to a generalist herbivore, defence and growth of invasive and native Senecio species: testing the evolution of increased competitive ability hypothesis. Oecologia 159:95-106

Cipollini D, Mbagwu J, Barto K, Hillstrom C, Enright S (2005) Expression of constitutive and inducible chemical defenses in native and invasive populations of Alliaria petiolata. J Chem Ecol 31:1255-1267

Connor EF, Faeth SH, Simberloff D, Opler PA (1980) Taxonomic isolation and the accumulation of herbivorous insects - a comparison of introduced and native trees. Ecol Entomol 5:205-211

Coombs E, Clark J, Piper G, Cofrancesco Ae Jr (2004) Biological control of invasive plants in the United States. Oregon State University Press, Corvallis

Craig AM, Blythe LL, Lassen ED, Slizeski ML (1986) Resistance of sheep to pyrrolizidine alkaloids. Isr J Vet Medicin 4:376-384

Easteal S (1981) The history of introductions of bufo-marinus (Amphibia, Anura) — a natural experiment in evolution. Biol J Linn Soc 16:93

Eigenbrode SD, Andreas JE, Cripps MG, Ding H, Biggam RC, Schwarzlander M (2008) Induced chemical defenses in invasive plants: a case study with Cynoglossum officinale L. Biol Invasions 10:1373-1379

Eisner T, Eisner M (1991) Unpalatability of the pyrrolizidine alkaloid containing moth, Utetheisa ornatrix, and its larva, to wolf spiders. Psyche 98:111-118

Feeny PP (1976) Plant apparency and chemical defence. Rec Adv Phytochem 10:1-40

Feng YL, Lei YB, Wang RF, Callaway RM, Valiente-Banuet A, Inderjit, Li YP, Zheng YL (2009) Evolutionary tradeoffs for nitrogen allocation to photosynthesis versus cell walls in an invasive plant. Proc Natl Acad Sci USA 106: $1853-1856$

Glawe GA, Zavala JA, Kessler A, Van Dam NM, Baldwin IT (2003) Ecological costs and benefits correlated with trypsin protease inhibitor production in Nicotiana attenuata. Ecology 84:79-90

Hedges LV, Gurevitch J, Curtis PS (1999) The meta-analysis of response ratios in experimental ecology. Ecology 80 : 1150-1156 
Hull-Sanders HM, Clare R, Johnson RH, Meyer GA (2007) Evaluation of the evolution of increased competitive ability (EICA) hypothesis: loss of defense against generalist but not specialist herbivores. J Chem Ecol 33:781-799

Jakobs G, Weber E, Edwards PJ (2004) Introduced plants of the invasive Solidago gigantea (Asteraceae) are larger and grow denser than conspecifics in the native range. Divers Distrib 10:11-19

Joshi J, Vrieling K (2005) The enemy release and EICA hypothesis revisited: incorporating the fundamental difference between specialist and generalist herbivores. Ecol Lett 8:704-714

Keane RM, Crawley MJ (2002) Exotic plant invasions and the enemy release hypothesis. Trends Ecol Evol 17:164-170

Koricheva J (2002) Meta-analysis of sources of variation in fitness costs of plant antiherbivore defenses. Ecology 83:176-190

Koricheva J, Nykanen H, Gianoli E (2004) Meta-analysis of trade-offs among plant antiherbivore defenses: are plants jacks-of-all-trades, masters of all? Am Nat 163:E64-E75

Lewis KC, Bazzaz FA, Liao Q, Orians CM (2006) Geographic patterns of herbivory and resource allocation to defense, growth, and reproduction in an invasive biennial, Alliaria petiolata. Oecologia 148:384-395

Long JL (2003) Introduced mammals of the world: their history, distribution and influence. CABI Publishing, Oxford

Máčel M, Vrieling K (2003) Pyrrolizidine alkaloids as oviposition stimulants for the cinnabar moth, Tyria jacobaeae. J Chem Ecol 29:1435-1446

Maron JL, Vila M, Arnason J (2004) Loss of enemy resistance among introduced populations of St. John's Wort (Hypericum perforatum). Ecology 85:3243-3253

Müller C, Martens N (2005) Testing predictions of the 'evolution of increased competitive ability' hypothesis for an invasive crucifer. Evol Ecol 19:533-550

Müller-Schärer H, Schaffner U, Steinger T (2004) Evolution in invasive plants: implications for biological control. Trends Ecol Evol 19:417-422

Read J, Sanson GD, Caldwell E, Clissold FJ, Chatain A, Peeters P, Lamont BB, De Garine-Wichatitsky M, Jaffre T, Kerr S (2009) Correlations between leaf toughness and phenolics among species in contrasting environments of Australia and New Caledonia. Ann Bot 103:757-767

Rejmanek M (2000) Invasive plants: approaches and predictions. Austral Ecol 25:497-506

Rhoades DF, Cates RG (1976) Toward a general theory of plant antiherbivore chemistry. Rec Adv Phytochem 10:168-213
Ridenour WM, Vivanco JM, Feng YL, Horiuchi J, Callaway RM (2008) No evidence for trade-offs: centaurea plants from America are better competitors and defenders. Ecol Monogr 78:369-386

Roderick ML, Berry SL, Noble IR, Farquhar GD (1999) A theoretical approach to linking the composition and morphology with the function of leaves. Funct Ecol 13:683-695

Siemann E, Rogers WE (2001) Genetic differences in growth of an invasive tree species. Ecol Lett 4:514-518

Smith WK, Nobel PS (1977) Influences of seasonal-changes in leaf morphology on water-use efficiency for 3 desert broadleaf shrubs. Ecology 58:1033-1043

Stamp N (2003) Out of the quagmire of plant defense hypotheses. Q Rev Biol 78:23-55

Strauss SY, Siemens DH, Decher MB, Mitchell-Olds T (1999) Ecological costs of plant resistance to herbivores in the currency of pollination. Evolution 53:1105-1113

Travers-Martin N, Müller C (2008) Matching plant defence syndromes with performance and preference of a specialist herbivore. Funct Ecol 22:1033-1043

Van Dam NM, Vrieling K (1994) Genetic-variation in constitutive and inducible pyrrolizidine alkaloid levels in cynoglossum-officinale L. Oecologia 99:374-378

Van der Meijden E (1996) Plant defence, an evolutionary dilemma: contrasting effects of (specialist and generalist) herbivores and natural enemies. Entomol Exp Appl 80:307-310

Van der Meijden E, de Boer NJ, van der Veen-van Wijk CAM (2000) Pattern of storage and regrowth in ragwort. Evol Ecol 14:439-455

Vrieling K, van Wijk CAM (1994) Cost assessment of the production of pyrrolizidine alkaloids in ragwort (SenecioJacobaea L). Oecologia 97:541-546

Vrieling K, de Vos H, van Wijk CAM (1993) Genetic-analysis of the concentrations of pyrrolizidine alkaloids in seneciojacobaea. Phytochemistry 32:1141-1144

Weller SJ, Jacobson NL, Conner WE (1999) The evolution of chemical defences and mating systems in tiger moths (Lepidoptera: Arctiidae). Biol J Linn Soc 68:557-578

Wikström SA, Steinarsdottir MB, Kautsky L, Pavia H (2006) Increased chemical resistance explains low herbivore colonization of introduced seaweed. Oecologia 148: 593-601

Willis AJ, Thomas MB, Lawton JH (1999) Is the increased vigour of invasive weeds explained by a trade-off between growth and herbivore resistance? Oecologia 120:632-640 